\title{
Accessibility Pattern of Information and Communication Technologies among Field Functionaries of Haryana, India
}

\author{
Noor Agha, B.S. Ghanghas" and P.K. Chahal \\ Department of Extension Education, CCS Haryana Agricultural University, Hisar-125004, \\ Haryana, India \\ *Corresponding author
}

\begin{abstract}
A B S T R A C T
Information and Communication Technology has become an effective tool for transforming agriculture from traditional resource based method of production to a new science based method and commercialized agriculture in digitalized global village. The findings indicated that 44.4 percent of extension personnel had ICT facilities in their department among which computer and printer facilities were possessed by half of the

respondents while facility of internet and digital camera were possessed by 30.0 percent of respondents. LCD projector facility essential for trainings and play of videos was possessed by about 20.00 percent of respondents which is pivotal for transfer of technologies in easy and understandable way resource poor farmers. Accessibility pattern highlighted that computer was most accessed with mean score of 1.67 followed by digital camera 1.52 mean score and printer with mean score 1.47 while, LCD projector and GPRS device were least accessed with mean score of 0.34 and 0.57 respectively for extension activities by field functionaries. Further exploration of actual use of computer indicated browsing the internet for search of agricultural information followed by documentation, social media for dissemination of information, e-mail, MS Power Point and, use of expert system for technical advisory. Majority of the extension personnel perceived ICTs very useful in time saving, more outreach, cost saving, access to more information sources, more effective with better communication and portability. Sincere efforts should be made by government to provide computers/laptop with internet facility along with specialized training on ICTs to all field functionaries to enhance their efficiencies to achieve desirable outcomes and long term impact of farming situation and resource base extension activities on farming community.
\end{abstract}

\section{Keywords}

Field Functionaries,

Information and

Communication

Technologies,

Accessibility, Perception

Article Info

Accepted:

20 April 2018

Available Online:

10 May 2018

\section{Introduction}

The Information and Communication Technology (ICT) is not only one of the driving forces of globalization but it played important role in liberalization of world trade in the field of agriculture responsible for agripreneurship development across the world.
Integration of ICT is rapidly transforming the way of agricultural technology transfer. The ICT enabled extension systems are acting as a key agent for changing agrarian situation and farmers' lives by improving access to reliable, timely and relevant information and sharing knowledge as well. Information and Communication Technology (ICT) in 
agricultural extension can lead to the emergence of knowledgeable workers that will result in the realization of a bottom-up, demand driven paradigm for technology generation, assessment and refinement and transfer of new and modern technologies (Meera and Rao 2004). A strong agricultural extension linkage complemented by flawless information flow enhanced by the effective use of ICTs will significantly boost agricultural production, productivity, income and improve rural livelihoods in developing countries (Arokoyo, 2005).

Compelling need for current Agricultural Knowledge and Information System (AKIS) by farmers in the era of climate change, world globalization and liberalization leading to agri-prenuership, the use of conventional communication channels become less effective. One way to address this is through the adoption of ICTs by both researchers and extension workers to transmit the relevant information to farmers in most effective and efficient way. Since the situation assessment survey of farmers conducted during the $59^{\text {th }}$ round of National Sample Survey (NSSO, 2005) provided valuable insights into reach of extension services across India. The public sector extension worker was a source of information for only 5.7 per cent of farmer households interviewed. Survey showed that 60 per cent of farm households did not access any information on modern technology.

The insufficient extension staff and financial constraints make agricultural extension more difficult. Study reveals that extension through contact is difficult as ratio of staffs to farmers varies widely from 1:300 in Kerala to 1:2000 in Rajasthan. The Situation Assessment Survey 2013 posited that traditional and modern ICTs (Newspaper, radio, television and internet) have also assumed important role as source of information of farmers. At the allIndia level, $41 \%$ of cultivating households accessed technical help from any source during reference period (July-December 2012). Public extension agencies, including extension workers, KVKs and SAUs were a source of information for around 10 percent of households (NSSO 2014)

At present use of information communication technology in agricultural extension system is far from satisfaction. Keeping in view the aforementioned facts the study was undertaken with the following objectives:

To assess the availability and accessibility of ICTs among the field functionaries

To find out the differential use of computer by extension personnel for different extension activities.

Perception of field functionaries regarding use of modern ICTs in extension work

To study the association between sociopersonal characteristics of the extension personnel and use of ICTs

\section{Materials and Methods}

To collect the primary data on use of information and communication technologies by extension personnel to disseminate agricultural information, the respondents were selected with multistage sampling. The zone-1 of the country comprising five states (Delhi, Himachal Pradesh, Haryana, Jammu \& Kashmir and Punjab) was selected purposively having the food bowl of the nation and from selected zone Haryana was selected purposively due to direct access of the investigators. Hisar and Fatehabad districts of state were selected since being in the vicinity of CCSHAU, Hisar being nodal training centre for imparting monthly trainings to the extension personnel of state department of agriculture and easy access to the 
investigators. By census method all field functionaries i.e. Agricultural Development Officers (ADOs) and Block Agricultural Officers (BAOs) working in department of agriculture of both districts was selected. Accordingly there were 44 ADOs and 6 BAOs in Hisar and 40 ADOs in Fatehabad making thus total 90 extension personnel's data complete in all respect was considered for analysis and reporting. The data were collected with the help of well-structured and pretested schedule comprising the items for use of ICTs by field functionaries, constraints encountered by them and perception related to consequences of no use of these tools of communication. The descriptive statistical measures like frequency, percentage, mean, rank order analysis and chi-square test were used to analyze the data to draw tangible inferences.

\section{Results and Discussion}

The results along with relevant discussion have been presented in prime heads availability and accessibility of ICTs among the field functionaries, use of computer by extension personnel for different extension activities, perception of field functionaries regarding use of modern ICTs in extension work and association between socio-personal characteristics of the extension personnel and use of ICTs.

Availability and accessibility of information and communication technologies (ICTs) among the field functionaries

\section{Availability of ICT facilities in department and at work place}

The results pertaining to availability of ICT facilities in department presented in Figure 1 clearly depicts that only 44.4 percent of respondents had ICT facilities in their departments.
The data pertaining to ICTs facilities at their disposal at their work place presented in Table 1 reveals that more than half $(57.8 \%)$ of the extension personnel had computers followed by computer printers $(50.0 \%)$, mobile phone (32.2\%), internet connection 31.1percent and 30.0 percent had digital cameras at their work place and a mere 18.9 percent had LCD projectors.

It can be concluded that half of the respondents have computer and printer facilities in their work place while facility of internet and digital camera were possessed by 30.0 percent of respondents.

LCD projector facility essential for trainings and play of videos was possessed by about 20.00 percent of respondents. The state department of agricultural should increase all ICT facilities specially, LCD projector to all extension personnel.

These finding are in consonance with earlier study of Karanja (2014) who found that only 32.2 percent of the respondent had basic access to ICT devices at their offices. i.e., $51.5 \%$ of the extension personnel had computers followed by 47.5 percent internet connection, 45.5 percent computer printers, 29.7 percent digital cameras, 15.5 percent telephone lines and a mere 3 percent LCD projectors at their work place.

\section{Accessibility sources of ICT devices}

The data pertaining to accessibility sources of ICT devices presented in Table 2 it is very much clear that computer was most accessed and top ranked with mean score of 1.67, digital camera second rank with 1.52 mean score and followed by printer with mean score 1.47 while, LCD projector and GPRS device were less accessed respectively with mean score 0.34 and 0.57 respectively for extension activities by field functionaries. 
Table.1 Availability of ICT facilities at place of work of extension personnel

\begin{tabular}{|c|l|c|c|}
\hline S. No. & \multicolumn{1}{|c|}{ ICT facilities at work place } & Frequency & Percentage \\
\hline 1. & Computer & 52 & 57.8 \\
\hline 2. & Internet & 28 & 31.1 \\
\hline 3. & printer & 45 & 50.0 \\
\hline 4. & Digital camera & 27 & 30.0 \\
\hline 5 & LCD projector & 17 & 18.9 \\
\hline 6 & Mobile phone & 29 & 32.2 \\
\hline
\end{tabular}

Table.2 Accessibility pattern of ICT devices among extension personnel

\begin{tabular}{|c|c|c|c|c|c|c|c|}
\hline \multirow{2}{*}{$\begin{array}{l}\text { Types of ICT } \\
\text { device }\end{array}$} & \multicolumn{4}{|c|}{ Place/source of access of ICT device } & \multirow{2}{*}{$\begin{array}{l}\text { Total } \\
\text { score }\end{array}$} & \multirow{2}{*}{$\begin{array}{l}\text { Mean } \\
\text { score }\end{array}$} & \multirow{2}{*}{$\begin{array}{l}(\mathrm{n}=90) \\
\text { Rank } \\
\text { order }\end{array}$} \\
\hline & $\begin{array}{c}\text { Place of } \\
\text { work } \\
\text { (3) }\end{array}$ & $\begin{array}{l}\text { Cybercafé } \\
\text { /Hire } \\
\text { (2) }\end{array}$ & $\begin{array}{c}\text { Own } \\
\text { (1) }\end{array}$ & $\begin{array}{l}\text { No access } \\
\text { (0) }\end{array}$ & & & \\
\hline Computer & $\begin{array}{c}35 \\
(38.9)\end{array}$ & $\begin{array}{c}5 \\
(5.6)\end{array}$ & $\begin{array}{c}35 \\
(38.9)\end{array}$ & $\begin{array}{c}15 \\
(16.6)\end{array}$ & 150 & 1.67 & I \\
\hline Internet & $\begin{array}{c}16 \\
(17.8)\end{array}$ & $\begin{array}{c}5 \\
(5.6)\end{array}$ & $\begin{array}{c}48 \\
(53.3)\end{array}$ & $\begin{array}{c}21 \\
(23.3)\end{array}$ & 106 & 1.177 & IV \\
\hline Printer & $\begin{array}{c}34 \\
(37.7)\end{array}$ & $\begin{array}{c}7 \\
(7.7)\end{array}$ & $\begin{array}{c}17 \\
(18.9)\end{array}$ & $\begin{array}{c}32 \\
(35.7)\end{array}$ & 133 & 1.47 & III \\
\hline Digital camera & $\begin{array}{c}26 \\
(28.9)\end{array}$ & $\begin{array}{c}3 \\
(3.3)\end{array}$ & $\begin{array}{c}23 \\
(25.6)\end{array}$ & $\begin{array}{c}38 \\
(42.2)\end{array}$ & 137 & 1.52 & II \\
\hline LCD projector & $\begin{array}{c}7 \\
(7.8)\end{array}$ & $\begin{array}{c}4 \\
(4.4)\end{array}$ & $\begin{array}{c}2 \\
(2.2)\end{array}$ & $\begin{array}{c}77 \\
(85.6)\end{array}$ & 31 & 0.34 & VII \\
\hline Mobile phone & $\begin{array}{c}6 \\
(6.7)\end{array}$ & - & $\begin{array}{c}75 \\
(85.5)\end{array}$ & $\begin{array}{c}7 \\
(7.8)\end{array}$ & 97 & 1.07 & V \\
\hline GPRS device & $\begin{array}{c}14 \\
(15.6)\end{array}$ & - & $\begin{array}{c}9 \\
(10.0)\end{array}$ & $\begin{array}{c}66 \\
(74.4)\end{array}$ & 52 & 0.57 & VI \\
\hline
\end{tabular}


Table.3 Use of computer by extension personnel for different extension activities

\begin{tabular}{|c|c|c|c|c|c|c|c|c|c|c|c|c|c|c|c|c|}
\hline \multirow{3}{*}{$\begin{array}{l}\text { Sr. } \\
\text { No. }\end{array}$} & \multirow{3}{*}{ Activities } & \multirow{2}{*}{\multicolumn{2}{|c|}{$\begin{array}{l}\text { Never } \\
(0)\end{array}$}} & \multirow{2}{*}{\multicolumn{2}{|c|}{$\begin{array}{l}\text { Least } \\
\text { (1) }\end{array}$}} & \multirow{2}{*}{\multicolumn{2}{|c|}{$\begin{array}{l}\text { Rarely } \\
\text { (2) }\end{array}$}} & \multirow{2}{*}{\multicolumn{2}{|c|}{$\begin{array}{c}\text { Occasionally } \\
\text { (3) }\end{array}$}} & \multirow{2}{*}{\multicolumn{2}{|c|}{$\begin{array}{l}\text { Some } \\
\text { time (4) }\end{array}$}} & \multirow{2}{*}{\multicolumn{2}{|c|}{$\begin{array}{c}\text { Mostly } \\
\text { (5) }\end{array}$}} & & & \\
\hline & & & & & & & & & & & & & & \multirow[t]{2}{*}{$\begin{array}{l}\text { Total } \\
\text { score }\end{array}$} & \multirow[t]{2}{*}{$\begin{array}{l}\text { Mean } \\
\text { score }\end{array}$} & \multirow[t]{2}{*}{$\begin{array}{l}\text { Rank } \\
\text { order }\end{array}$} \\
\hline & & n & $\%$ & $\mathbf{n}$ & $\%$ & $\mathbf{n}$ & $\%$ & $\mathbf{n}$ & $\%$ & $\mathbf{n}$ & $\%$ & $\mathbf{n}$ & $\%$ & & & \\
\hline 1. & $\begin{array}{l}\text { Browsing the } \\
\text { internet for } \\
\text { search of social } \\
\text { media for } \\
\text { dissemination }\end{array}$ & 19 & 21.1 & 22 & 24.2 & 8 & 8.9 & 11 & 12.2 & 7 & 7.8 & 23 & 25.6 & 214 & 2.37 & III \\
\hline 2. & $\begin{array}{l}\text { Browsing the } \\
\text { internet for } \\
\text { search of } \\
\text { agricultural } \\
\text { information }\end{array}$ & 15 & 16.7 & 16 & 17.8 & 8 & 8.9 & 8 & 8.9 & 11 & 12.2 & 32 & 35.6 & 260 & 2.88 & I \\
\hline 3. & $\begin{array}{l}\text { Document } \\
\text { preparation: } \\
\text { word processing }\end{array}$ & 24 & 26.7 & 15 & 16.7 & 6 & 6.7 & 15 & 16.7 & 11 & 12.2 & 19 & 21.1 & 215 & 2.38 & II \\
\hline 4. & $\begin{array}{l}\text { Numerical } \\
\text { work: Spread } \\
\text { sheets }\end{array}$ & 32 & 35.6 & 18 & 20 & 4 & 4.4 & 18 & 20 & 4 & 4.4 & 14 & 15.6 & 166 & 1.84 & VII \\
\hline 5. & $\begin{array}{l}\text { Presentation } \\
\text { graphics: MS } \\
\text { power point }\end{array}$ & 30 & 33.3 & 16 & 17.8 & 12 & 13.3 & 6 & 6.7 & 6 & 6.7 & 20 & 22.2 & 182 & 2.02 & V \\
\hline 6. & $\begin{array}{l}\text { Graphic design: } \\
\text { Desktop } \\
\text { publishing }\end{array}$ & 46 & 51.1 & 26 & 28.9 & 2 & 2.2 & 3 & 3.3 & 4 & 4.4 & 9 & 10.0 & 100 & 1.12 & XI \\
\hline 7. & Programming & 47 & 52.2 & 22 & 24.2 & 1 & 1.1 & 7 & 7.8 & 4 & 4.4 & 9 & 10.0 & 105 & 1.16 & $X$ \\
\hline 8. & $\begin{array}{l}\text { System/Network } \\
\text { administration }\end{array}$ & 52 & 57.8 & 18 & 20 & 4 & 4.4 & 8 & 8.9 & 2 & 2.2 & 6 & 6.7 & 88 & 0.97 & XIII \\
\hline 9. & Geospatial work & 50 & 55.6 & 20 & 22.2 & 3 & 3.3 & 8 & 8.9 & 3 & 3.3 & 6 & 6.7 & 92 & 1.02 & XII \\
\hline 10. & E-mail & 20 & 22.2 & 16 & 17.8 & 8 & 8.9 & 12 & 13.3 & 11 & 12.2 & 23 & 25.6 & 191 & 2.12 & IV \\
\hline 11. & Entertainment & 35 & 38.6 & 19 & 21.1 & 11 & 12.2 & 6 & 6.7 & 7 & 7.8 & 12 & 13.3 & 130 & 1.44 & VIII \\
\hline 12. & $\begin{array}{l}\text { Dissemination } \\
\text { of agricultural } \\
\text { information by } \\
\text { updating the } \\
\text { web page or } \\
\text { website }\end{array}$ & 38 & 42.2 & 26 & 28.9 & 8 & 8.9 & 7 & 7.8 & 5 & 5.6 & 6 & 6.7 & 113 & 1.25 & IX \\
\hline 13. & $\begin{array}{l}\text { Run of any } \\
\text { CSC, VRC in } \\
\text { the village of } \\
\text { extension } \\
\text { personnel } \\
\text { operational } \\
\text { area? }\end{array}$ & 50 & 55.6 & 24 & 26.7 & 2 & 2.2 & 6 & 6.7 & 4 & 4.4 & 4 & 4.4 & 82 & 0.91 & XIV \\
\hline 14. & $\begin{array}{l}\text { Use of expert } \\
\text { system for } \\
\text { technical } \\
\text { advisory } \\
\text { guidance? }\end{array}$ & 33 & 36.7 & 20 & 22.2 & 6 & 6.7 & 10 & 11.1 & 13 & 14.4 & 8 & 8.9 & 168 & 1.86 & VI \\
\hline
\end{tabular}


Table.4 Association between socio-personal characteristics of the extension personnel facilities at work place

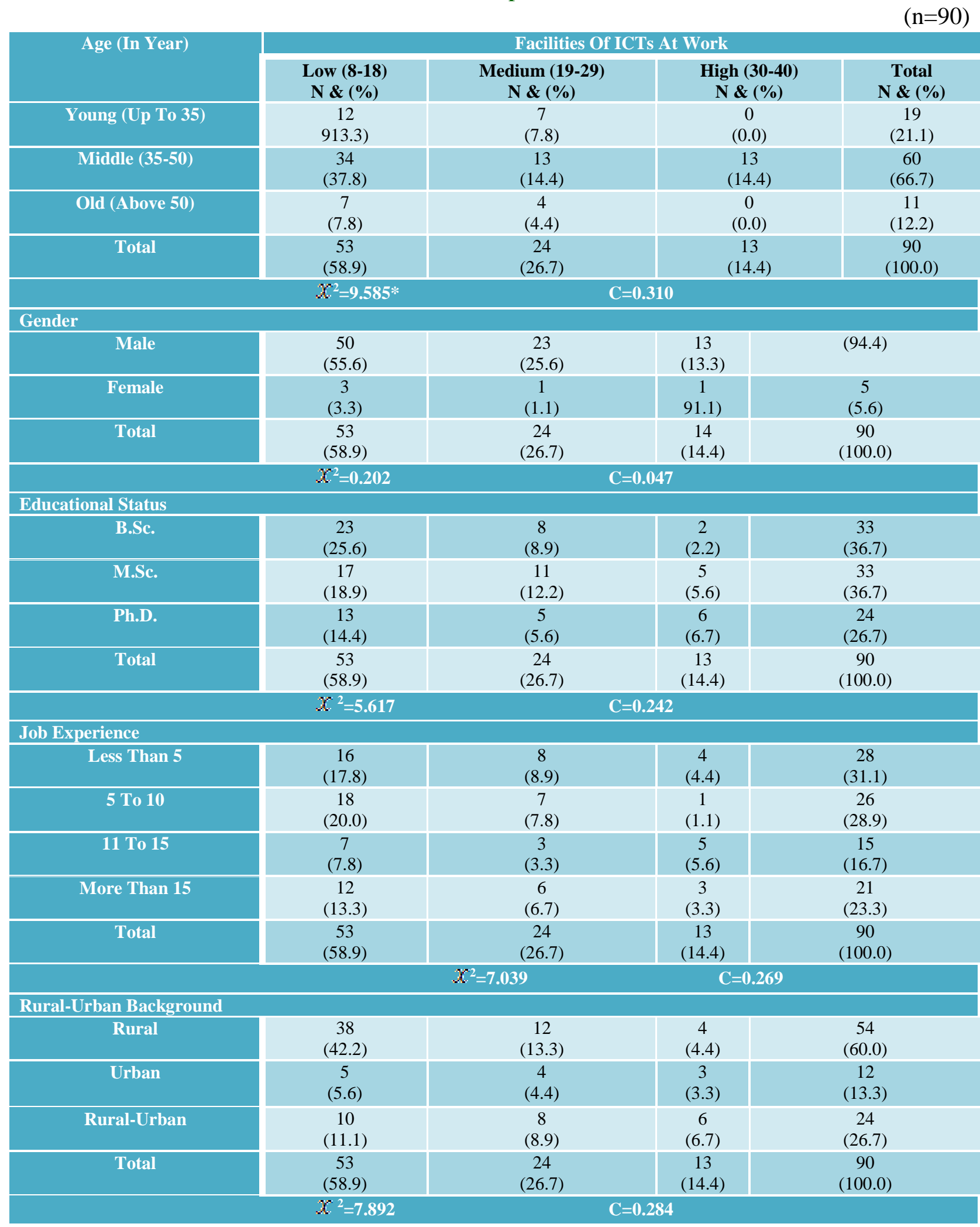

* Significant at.05 percent level; **Highly significant at.01 percent level 
Table.5 Association between socio-personal characteristics and activities with computer by extension personnel

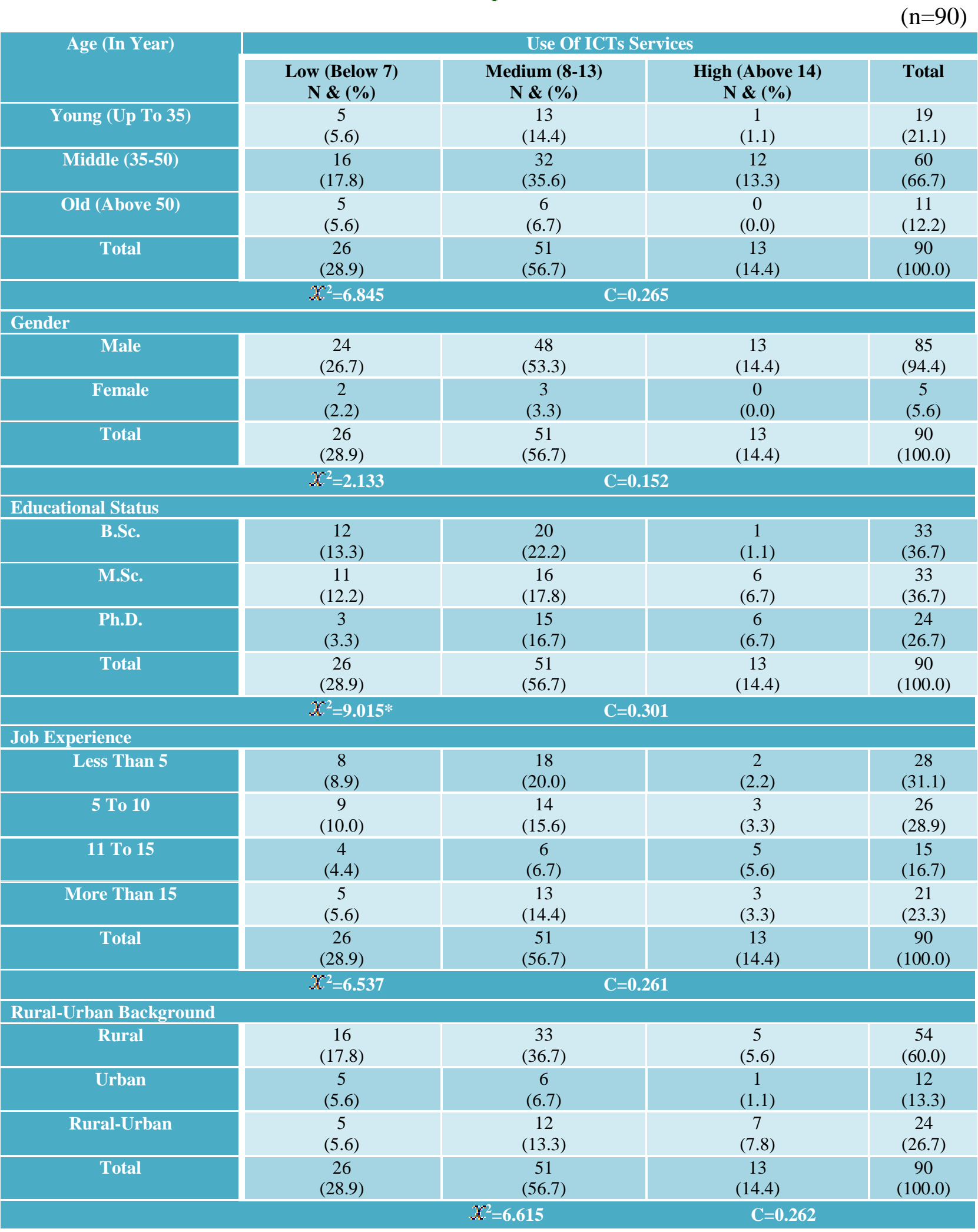

* Significant at.05 percent level; **Highly significant at.01 percent level 
Fig.1 Availability of ICTs facilities in departments of extension personnel

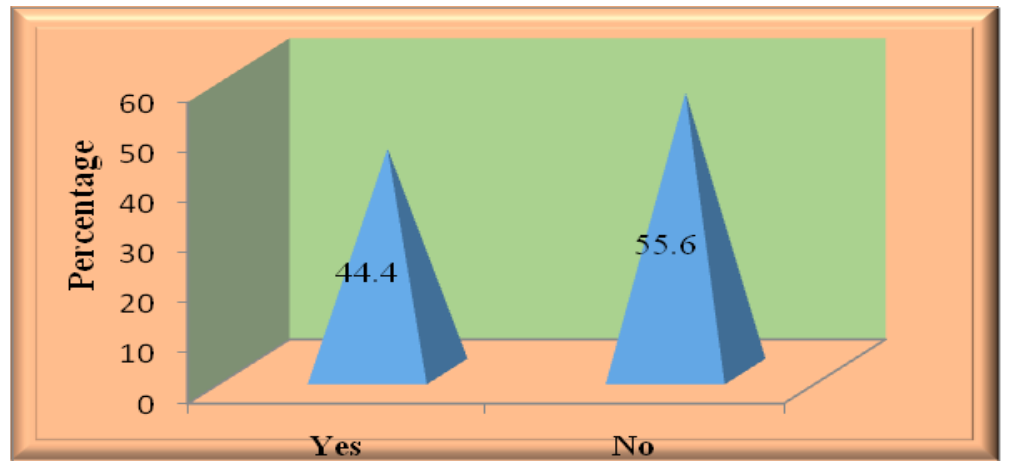

Fig.2 Perception of field functionaries regarding use of modern ICTs in extension work

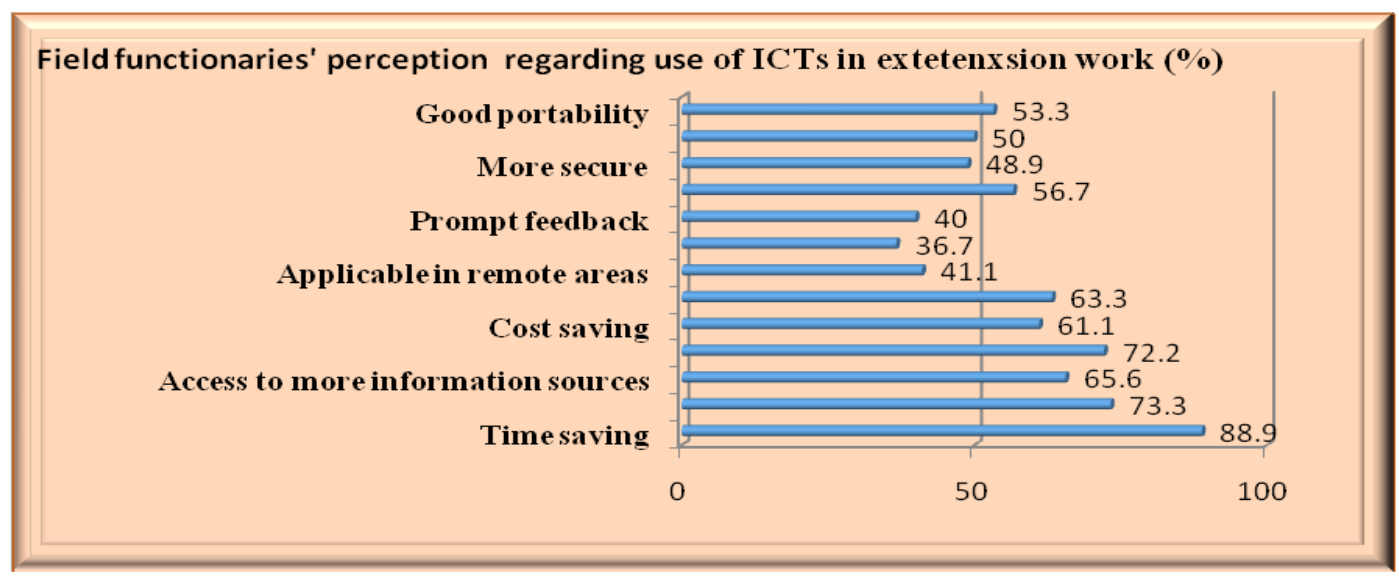

Findings pertaining to actual use of computer by extension personnel for different extension activities presented in Table 3 clearly show that majority of the respondents used computer for browsing the internet for search of agricultural information with mean score of 2.88 followed by word processing with the mean score 2.38 , browsing the internet for search of social media for dissemination with mean score 2.37, e-mail with mean score 2.12, presentation graphics (MS Power Point) with mean score 2.02, use of expert system for technical advisory with mean score 1.86 , numerical work with mean score 1.84 , entertainment with mean score 1.44 . The findings are contradictory to the findings of past study of Karanja (2014) who found that majority of the respondents used their computers mainly not related to agricultural information generation and dissemination. 40 percent of the extension personnel interviewed were found to use computers for entertainment, while 20 percent for document preparation, 15 percent for email and a partly 10 percent for sourcing agricultural information

Sincere efforts should be made by government to provide computers/laptop with internet facility to all field functionaries to enhance their efficiencies to achieve desirable outcomes and long term impact of farming situation and resource base extension activities on farming community.

\section{Perception of field functionaries regarding use of modern ICTs in extension work}

The results presented pertaining to perception of field functionaries regarding use of modern ICTs in Figure 2 it might be concluded that majority of the extension personnel perceived 
ICTs very useful as time saving, more outreach, cost saving, access to more information sources, more effective with better communication and portability. So government should do sincere efforts to promote the use of ICT tools for pragmatic and efficient extension work with maximum outreach.

\section{Association between socio-personal characteristics of the extension personnel and facilities at work place}

It is obvious from the data pertaining to association between socio-personal characteristics of the extension personnel and facilities at work place presented in Table 4 that only age of the respondent was significantly associated with the ICTs facilities at place of work of the respondents. Whereas variables like gender, educational status, rural-urban background and job experience of the respondents were not significantly associated with the ICTs facilities at place of work of the respondents.

\section{Association between socio-personal characteristics and activities with computer by extension personnel}

The association data presented in Table 5 shows that among five variables taken up for the study, only educational status of the respondent had significant association with the activities with the computer by the respondents. Whereas variables like age, gender rural-urban background and job experience of the respondents were not significantly associated with the using of computer by respondents

\section{References}

Anonymous 2014. Situation Assessment Survey of Agricultural Households, January December, NSSO 70th Round (2013). National Sample Survey Organization Ministry of Statistics and Programme Implementation (MOSPI), Government of India.

Arokoyo, T. 2005. ICTs application in agricultural extension service delivery. In: Adedoyin, S.F (ed) Agricultural Extension in Nigeria. Ilorin: Agricultural extension society of Nigeria.

Karanja, K.B. (2014). Use of modern communication technologies among rural agricultural extension personnel to disseminate agricultural information: Case study of Machakos County. M.Sc. thesis in Agricultural Information and Communication Management. University of Nairobi

Meera. Shaik N. and Rao. D.U.M. 2004. Information and communication technology in agricultural development: A comparative analysis of three projects from India. Agricultural Research and Extension Network. Network paper No.135.

Noor Agha, B.S. Ghanghas and Chahal, P.K. 2018. Use of Information and Communication Technologies by Extension Personnel to Disseminate Agricultural Information. International Journal of Current Microbiology and Applied Sciences 7(4): 1369-1376.

Rohila, A. K., Krishan Yadav and Ghanghas, B.S. 2017. Role of information and communication technology (ICT) in agriculture and extension. Journal of Applied and Natural Science. 9 (2): 10971100.

\section{How to cite this article:}

Noor Agha, B.S. Ghanghas and Chahal, P.K. 2018. Accessibility Pattern of Information and Communication Technologies among Field Functionaries of Haryana, India. Int.J.Curr.Microbiol.App.Sci. 7(05): 2737-2745. doi: https://doi.org/10.20546/ijcmas.2018.705.317 